\title{
Sunset in the West: \\ outsourcing editorial work from the UK to India - a case study of the impact on workers
}

\author{
Simone Dahlmann \\ Ursula Huws
}

Simone Dahlmann is a research fellow at Analytica and at the Working Lives Research Institute at London Metropolitan University where she also teaches social research methods.

Ursula Huws is professor of International Labour Studies at the Working Lives Research Institute at London Metropolitan University in the UK and the director of Analytica.

\begin{abstract}
This paper presents a case study carried out in a large academic publishing and printing house. Interviews were carried out in both locations with senior and middle management, workers and trade unionsto gain their perspectives on the outsourcing of typesetting and editorial work from the UK to India. In Britain, 'working in publishing' traditionally represented a prestigious and highly sought-after career for graduates with high skills, both generic and occupation-specific. This paper explores the shock experienced by these workers when faced with the prospect of losing their jobs to the Indian labour market and argues that the outsourcing of skilled work in an increasingly globalised labour market introduces new forms of precariousness even to highly qualified workers with diverse skills. However the study also finds that the workers in India who are taking over these tasks are not experiencing the benefits previously enjoyed by their British counterparts. On the contrary, on the evidence of this case study, their jobs too are highly insecure. It concludes that the qualitative effects of offshore outsourcing on employment are more important than quantitative impacts.
\end{abstract}

\section{'Let's face it. We have to accept that publishing is now a sunset labour market in Britain'.}

This astonishing statement was made in 2003, not by the boss of a transnational multimedia empire but by a trade union representative in the country that produced Shakespeare, Jane Austen and the first printed books and newspapers in what is now the dominant global language. He was being interviewed as part of a case study on the relocation of skilled editorial work from England to India by a large and highly regarded academic publisher. The impact of that relocation on the British workforce and on their Indian counterparts is the topic of this article.

\section{The relocation of telemediated work}

The case study presented in this paper was carried out as part of the larger EMERGENCE group of projects. EMERGENCE (the acronym stands for 'estimation and mapping of employment relocation in a global economy in the new communications environment') was initially funded by the European Commission in 2000 with the aim of mapping and 
measuring the relocation of telemediated work ${ }^{1}$ around the globe. In the first phase of its work, the project carried out a survey of nearly 8,000 employers across the (then) 15 European Union Member States plus the three largest of the states that joined the EU in the subsequent wave of expansion (Hungary, Poland and the Czech Republic). A parallel survey was also carried out in Australia, involving 1,000 employers.

The survey, some of whose results are summarised in Table 1 , found that a wide range of business services were being relocated using telecommunications links, either on an outsourced basis or by companies setting up remote back offices. In the 18 European countries, seven per cent of the establishments interviewed had established remote back offices in other regions and around one in ten made use of teleworkers to deliver work from multiple locations. These were, however, strongly outnumbered by those who outsourced information work, either to individual freelancers (11 per cent) or to companies (43 per cent). Whilst most of the companies to which work was outsourced were in the same region or another region in the same country, a significant number were based abroad. In all, nearly six per cent of all the companies sampled outsourced at least one business service to another country using a telecommunications link. Around one company in five was involved in supplying outsourced services to customer organisations.

\section{Table 1: Employers' use of remote telemediated work in Europe, 2000}

\begin{tabular}{|l|l|}
\hline Any remote telemediated work & $\%$ \\
\hline Within the organisation (in-house) & 49 \\
\hline Employees working in remote back offices & \\
\hline Multilocational teleworking employees & 6.8 \\
\hline Home-based teleworking employees & 9.9 \\
\hline Employees working in third-party premises & 1.4 \\
\hline Purchasers of outsourced telemediated services & 0.9 \\
\hline Any 'e-outsourcing' (using telecommunications for delivery) & 43.0 \\
\hline 'eLancers' (freelancers using telecommunications for delivery) & 11.4 \\
\hline 'eOutsourcing' within own region & 34.5 \\
\hline 'eOutsourcing' to other region in same country & 18.3 \\
\hline 'eOutsourcing to another country & 5.3 \\
\hline Suppliers of outsourced telemediated services & 21.0 \\
\hline
\end{tabular}

Source: EMERGENCE European Employer Survey, 2000 (IES/NOP) Weighted figures; per cent of establishments with $>50$ employees in EU (15) plus Hungary, Poland and Czech Republic. Weighted base: 7305 cases

What were they outsourcing? The unit of analysis developed for use in this survey was

1 The term 'telemediated work' refers to work that can be digitised and transmitted over a telecommunications link to a remote destination. 
the 'generic business function'. Seven of these business functions were identified: creative and content-generating activities including research and development and design; software development and support (conceptually speaking software development is a sub-category of design but was deemed to be sufficiently well-defined and economically important to treat separately); data entry and typing (the routinised low-skill part of content-generation); management functions (including human resource management and the training of workers as well as logistics management); financial functions; sales activities, and customer service (which included the provision of advice and information to the public as well as after-sales support). There was of course some overlap between these categories and they were not exhaustive but they did provide a more stable and internationally comparable unit of analysis than the highly-problematic 'sector' or the rapidly-changing and culturally specific 'occupation' which were the alternative available units of classification.

The two groups of activities of most interest in this context are 'creative and content-generating functions' and 'software development and support'. Interestingly enough, these were also the two functions most likely to be outsourced. Nearly 30 per cent of the employers in the survey outsourced software development and IT support, and nearly 20 per cent outsourced design and creative work, whereas every other function was outsourced by less than 10 per cent of the sample (Huws and O'Regan, 2001). Some of this outsourcing was to locations outside Europe but much of it was supplied by companies based within the EU. Around one company in fourteen in the sample was involved in the supply of outsourced creative work, and one in sixteen in software supply. However instances of outsourced creative and IT work tended to involve smaller numbers of workers than lower-skilled activities such as data entry or customer service.

In the next stage of the research, in-depth case studies were carried out to explore the dynamics of this relocation of work and its impact on workers. In 2001 the EMERGENCE team carried out 62 case studies of organisations that had relocated work to another region or country using a telecommunications link for delivery of the work. Each case involved two separate investigations: one at the 'source' (the place from which the work originated) and one at the 'destination' (the place to which it was moved) and, occasionally, also further investigations at intermediate steps along the value chain. Of these cases (broadly reflecting the survey results) 14 involved 'software development and support'and ten involved 'creative and content-generating functions'. The latter included the movement of work between a Benelux country and Southeast Asia by a children's book publisher, a firm of architects based in a Scandinavian country whose design processes were distributed between Spain, Latin America and East Asia, and a company in Western Europe whose website design was outsourced, first to Poland and then, in a second step, to designers in Siberia, as well as a number of cases where creative work was outsourced or relocated within Europe (Flecker \& Kirschenhofer, 2002).

It was clear from the results of this research and from the results of EMERGENCE

$2 \quad$ Analysed another way (taking account of the fact that many establishments were involved in multiple outsourced arrangements), of all cases of outsourcing, 38.9 per cent per cent involved software development and 27.3 per cent involved creative functions (Huws and O'Regan, 2001:34). 
sister projects in Australia and Canada that the case studies carried out in 2001 reflected a particular moment in a rapidly-evolving reshuffling of the international division of labour. Early drivers of 'offshoring' (as it has come to be known) on the demand side included the skill shortages in routine programming created in Europe, the USA and other developed economies during the late 1990s by the rapid expansion of the internet, the 'millenium bug' and the conversion of European currencies to the euro (Huws, 2003). On the supply side, the collapse of the import substitution policies of economies like India and Brazil had made available on the global market a large supply of well-trained computer science graduates ${ }^{3}$. China had embraced the market economy (obliging Vietnam to do likewise) and the transitional economies of Central and Eastern Europe were also opening up their markets rapidly (Mako and Keszi, 2002). Although the EMERGENCE survey results suggested that the search for scarce skills was the most important driver of relocation in $2000^{4}$ (Huws and O'Regan, 2001), the bursting of the dot.com bubble and the consequent pressure on costs, we hypothesised, might lead to a shift in employers' strategies, with the search for low cost taking over as the dominant driver.

To investigate this hypothesis and explore further the impacts of offshore outsourcing on workers at the 'destination' as well as the 'source', funding was obtained in 2001 from the European Commission's Europeaid programme to carry out further case studies in Asia using the same methodology. In 2003, 59 case studies were carried out in India, Indonesia, the Philippines, Sri Lanka, Thailand, Malaysia and Vietnam. In order to study the relocations in full, these involved supplementary investigations at 'sources' or 'destinations' in Australia, Austria, Belgium, Canada, Finland, France, Germany, Luxembourg, Norway, Sweden, the UK and the USA as well as Hong Kong, and Singapore. As in the earlier EMERGENCE case studies, the largest group of cases (17) involved software development and support. However there were a number of cases involving high-skilled creative work. The functions involved included architectural drawing, graphic design, web design, research and development for three-dimensional modelling, detail design and the development of specialist products for the financial industry. Also in this category was the case study of specialised editorial work presented here (Huws and Flecker, 2004).

3 Before India loosened its trade regulations in 1992, these had largely been made available to employers in the UK and US through the mechanism of 'body shopping' whereby planeloads of Indian software engineers were sent to London or New York to work on temporary assignments (e.g. in the lead-up to the 'Big Bang' of 1986 when the London Stock Exchange went electronic) under employment contracts with their Indian employers. Tata Consultancy Services (TCS), the largest of the pre-1992 body-shoppers, used the client relationships built up during this period to launch itself subsequently as an offshore outsourcing supplier, as did several other major Indian players in the sector (interviews by Ursula Huws, Swasti Mitter and Sujata Gothaskhar carried out as part of the Telework and Teletrade in India and Malaysia project, 1996-7) were asked why they had chosen that particular supplier. Of the 4,154 reasons given in total,the largest number (22.9 per cent) were classifiable under the heading 'technical expertise and/or the right software/skills'; this was followed (at 12.6 per cent) by 'low cost/most competitive tender'. In descending order, the next most important reasons were 'good reputation/market leaders' (12.3 per cent), 'reliability/good quality/good attitude/creativity' (11.9 per cent) and 'longstanding relationship/strategic alliance/partnership' (9.1 per cent). 


\section{The Indian context}

After the relaxation of its trade in 1992, India became the most prominent destination for outsourcing of data entry, software development and other back office jobs. The statistics are notoriously unreliable (Huws, Flecker \& Dahlmann, 2004; Van Welsum, 2005) but most commentators agree that by the end of the 1990s it was the leading Asian supplier of business services (McCarthy, Belanger \& Orlov 2003 I). However this outsourcing had its roots in a much older trend. The UK publishing industry, for instance, had been sending typesetting and printing work to former colonies like Singapore, Hong Kong and Malta since the 1960s. The difference in the 1990s was the ability to use information and communications technologies (ICTs) for very fast and cheap delivery of work which previously had to be physically transported (Huws, 1996). India's assets were a large English-speaking population, well-trained IT specialists and well-educated graduates available to work in skilled jobs for low wages. Other advantages in the 1990s came from the rapid improvements in India's telecommunications infrastructure and time zone differences that made it possible to process work overnight and increase the speed of service to clients in Europe and the USA. All the evidence suggested that Indian companies were diversifying and moving up the value chain rapidly, extending the range of tasks assigned to their employees. It was predicted in 2003 that architecture and law companies would follow the financial and IT sectors into outsourcing (McCarthy, Belanger \& Orlov 2003) and in the same year, the Economist reported, that financial research \& analysis and desk-top publishing for banks and law firms was following back office work, cheque processing and data entry to India (the Economist February 2003).

\section{The UK context}

The case study must also be set in the context of broader trends in the British printing and publishing industries which have since the 1970s experienced a process of more or less continuous restructuring, partly because of a series of mergers, resulting in ever-larger global media conglomerates and partly as a result of technological change. During the 1980s, like severalother industries in Britain, publishing became extensively casualised (Huws, 1988). Many companies downsized their in-house workforce and substituted self-employed workers for permanent staff. There was a major expansion in the use of editorial home-based freelance work. Studies by Stanworth \& Stanworth $(1995,1997)$ documented the way that large numbers of formerly in-house editors and proof-readers in the UK book publishing industry had become self-employed freelancers, often still working for their previous employers. In the post-war period editorial work was seen as elite work, requiring at the very least a good university degree in English and often, also, specialist subject knowledge, as well as technical knowledge of the requirements of specific printing processes and some aesthetic or creative ability. It was typically done by people who saw themselves as intellectuals, often women who found it easier to enter than other, more competitive media industries such as television and advertising. The relatively low pay in the sector was offset by such (often illusory) advantages as meeting famous authors and becoming an insider in an intriguing 'world of letters'. In their study of freelancers, Stanworth and Stanworth (2007) showed that 
this reality was eroding under the pressures of casualisation. They concluded that the managerial impetus for creating a larger home-based freelance editorial staff was not just to reduce office overheads and cut costs but also to match staffing levels with peaks and troughs in demand, rendering the work very precarious and subject to unpredictable swings between 'feast' and 'famine'.

From the workers' perspective, publishing remained an attractive industry to work in, being associated with creativity and fame by association and seen as a route into a career 'in the media'. Thus college leavers and young graduates still competed to enter it, and were at least partially equipped to do so by an explosion in media studies degrees introduced during the expansion of higher education in Britain during the 1980s and 1990s. This fortified the trend towards a relocated, home-based freelance editorial workforce as these young people represented a continuous stream of available workers willing to sacrifice job security and benefits such as sick pay, holiday pay and pensions to their career ambitions. Further substantiation of this trend can be seen in the membership of the National Union of Journalists (NUJ) which represents the largest number of editorial workers in the UK publishing industry. By the mid 1980s, a third of the union's overall membership was self-employed, and the union's Books Branch had to set up a separate Freelance Section to represent their interests in the book publishing sector.

The fact that most of the workers in this case study chose to go freelance rather than accept deskilled work within the company suggests that this trend continues, with an ever-expanding swarm of freelancers competing for what may well turn out to be a dwindling supply of work. As one union member put it, "If you are made redundant in publishing, you are basically given the choice of "go freelance or leave the industry".' (Interview with Jenny Vaughan, member of the Freelance Industrial Council of the NUJ, 2004)

\section{The UK case study company}

The case study company is one of the oldest and largest publishers and printers in the UK, publishing over 2000 academic and educational books and 150 journals a year. As the printing and publishing house of a British university, with a subsidy for its work, the company traditionally enjoyed charitable status, giving it certain tax advantages. At the time of our research, in 2003, it employed around 800 staff in the UK, divided more or less equally between its publishing and printing divisions.

Towards the end of the 1990s the company decided to restructure. Its subsidised, charitable status was coming to an end and, under a new CEO, the management decided it needed to become more strategic and competitive. The company's performance was benchmarked against other printers and publishers and this exercise uncovered relative underperformance in many areas. On the advice of an external consultant, it was decided to outsource the most labour-intensive part of the production, the typesetting, to India. A few years later, two further steps were taken. First, the reading department was downsized substantially, leaving many readers and copy-editors without jobs. The editorial work that had previously been done in the 
UK was now moved to India. Second, a second Indian supplier was brought in. In an attempt to minimise the risks involved in dependence on a single supplier, the UK company's strategy was to divide the work between two different Indian offshore suppliers, each of whom were assigned to work on a number of journals and a few books. The underlying rationale was to relocate the work to the second offshore supplier if there were quality concerns with the work of the first. At the time of our research, for every three journals being sent for processing to the first supplier, approximately four were going to the second.

Back in the UK, the reading section was dismantled, and replaced by a new, digital services department. Sixty workers from the reading and origination area were faced with the choice of voluntary redundancy or redeployment. Because accepting redeployment meant being retrained in a range of IT skills and taking on work that was much more standardised and low-skilled than what they were used to, most of the readers and copy-editors accepted voluntary redundancy.

\section{The Indian case study company}

It was the first of the two Indian case study companies that formed the focus of our research. This was a new start-up company formed in 1996. The two founders had previously worked together in a typesetting machinery manufacturing company. Having observed first-hand the growth of offshored typesetting in India, they decided to use their existing networks to establish a position in this market. They gained their first two contracts - of which one was for the UK case study company - by personal recommendation and were only able to deliver the work by outsourcing to another company in another part of India. In the words of the Executive Director, 'We didn't have a clue in this business. We didn't even know how to price the orders and quote for them. Because of my relationship with those customers they told me how the publishing industry model works and how to price.' The company quickly built up its own staff, growing by about $60 \%$ per annum, and by 2003 was employing over 100 people and had acquired ISO 9001 certification $^{5}$. UK customers accounted for $60 \%$ of its business. In the early stages, this growth required an investment in training staff to use the proprietary software of the UK client case study company. The company did not only grow numerically but also moved up the value chain, expanding from doing typesetting to copy-editing, proof-reading and preparing journal articles for online publication. Interviewees at the company expressed confidence in the high quality of their work, spoke of the customer's satisfaction with it and their pride in the contribution they had made to helping this customer 'grow its business'.

Interestingly, when they were interviewed for this case study, it became clear that they did not know of the existence of the second Indian company to which increasing amounts of 'their' work was being transferred and were confident that the future they faced was one of continuing growth.

5

An internationally recognised quality standard. 


\section{The UK story}

In the UK, the case study involved unstructured qualitative interviews, on average around 60 minutes in length, with seven respondents from senior management, middle management, workers and the trade union.

\section{The UK workers' perspective}

All the copy-editors and readers in the company had undergone a traditional three- year apprenticeship, and most readers had been employed with the case company for many years. The reading department monitored the quality of work through proof-reading and copy-editing and supervised other processes, for example ensuring that deadlines were met. At the time of our interview, this quality monitoring process was being phased out in the UK, as part of the shift of responsibility to India. The 'second proofs' (the second stage of proof-reading) were still being checked in the UK company but soon all reading and copy-editing work would be in the hands of the offshore suppliers.

The UK workers remained very sceptical about Indian proof-reading and copyediting standards and expected a drop, pointing to previous experiences of spelling mistakes, errors in proper names and confusions between English and American usage. Workers described their feelings of resentment and shock when they were told about the redundancies. One interviewee remembers:

"It sounded so impossible, reading being done in India. I guess we always thought we were doing a privileged job that could not be done anywhere else, especially not by non-native speakers.'

Although most workers were offered the opportunity to be redeployed, 40 readers and copy-editors instantly accepted the voluntary redundancy package ${ }^{6}$; one reader remarked: "In this area people are in their 40s and 50s, they have no IT skills and are used to reading; there was no appeal in retraining to work with computers.'

Most of those who accepted voluntary redundancy planned to move into the precarious field of freelancing.

The experience of negotiating the change had left them feeling powerless, and, on the whole, disillusioned with their trade union. Once it became evident that management had made up their minds 'there was nothing we could do'. This feeling of powerlessness had generated resentment and frustration even amongst those who had not accepted redundancy. As one worker put it:

'Are we safe now or will there be more redundancies in the near future? We feel we were kept in suspense a long time when we didn't know if we'd have jobs.'

The fact that so many readers accepted voluntary redundancy created a shortfall of available workers. The company's solution was to bring in Indian workers to 'kill two birds with one stone' by simultaneously training the Indian workers and complementing the depleted workforce. Unsurprisingly, this created a real clash of interests. Workers who were asked to train their Indian counterparts wanted to go on strike and approached their trade union

6 In making this choice they were not behaving irrationally. Another study of the printing and publishing sector found very low levels of job satisfaction among proof-readers retrained to work on database management (Vendramin, Valenduc, Richardson, Carre et al 2000). 
with this in mind. However the trade union refused to support this plan and informed them that they were legally obliged to follow the management's orders. The workers experienced this as another 'slap in the face', as one reader put it, giving this as the main reason for deciding to take up freelance work.

A strong concern about quality emerged throughout the interviews; readers were very clear that they expected a steep drop in the quality of services offered by the case company and also felt that their management did not take this concern seriously because they were entirely driven by costs savings rather than customer satisfaction. This is reflected in the words of one copy-editor:

'Quality issues which used to be paramount no longer are; until customers complain, quality will drop'

Apart from general quality issues, workers expressed worries about the image of particular journals which they believe had set very high quality standards in the past. They doubted whether their Indian counterparts could keep these standards up.

'Being a graduate does not necessarily mean they're good at proof-reading I know there still will be mistakes, I am English that's why I don't get it wrong; my superiors don't want to see that - they think it will work because it is available.'

Despite their disillusioning experiences, workers still had a strong pride in their work and identification with the brand. There was considerable prestige attached to working for a traditional, academic publisher. Working morale was perceived to have been high amongst readers and copy-editors, but was now being replaced with feelings of frustration and disorientation. Interviewees remarked that there had always has been a very low staff turnover and most employees 'used to stay on average twenty years'. They reported that they had heard there was a high turnover in India in the reading department, with people staying for a maximum of three years. This gave them reason to doubt that workers there identify with the company's brand name.

'I am worried about the future, quality, the company's reputation and what our customers think about us.'

\section{The UK management's perspective}

The management's rationale for outsourcing was described as arising from necessity rather than choice. General market pressure was driving outsourcing to India in a bid to cut production costs. One manager said:

'People here are resentful, they feel that we are transferring their jobs to India. What they don't understand is that the real story is that this is something we had to do to offer competitive products.'

There was a strong belief that the redundancies had been approached and executed in a scrupulously fair manner and that the message was communicated carefully and transparently. One manager remarked:

'If you cut back in a humane way, if you are not greedy as a company about how quickly you want to cut down, people will understand,'

India was chosen because of the CEO's personal experience of working and travelling there. The main motives were to 'save on production costs' and gain access to a more flexible labour market. The management belief that the UK workforce needs to become 
more flexible is mirrored in the introduction of performance measures and greatertransparency 'to motivate employees'. This notion of greater flexibility is a critical one: it was believed that relaxed labour laws in India and less workers' protection enable companies to turn work around much more quickly. As one manager said:

'People in India are more flexible in what they will do. If you say to them "I'll pay you so much for so many hours work but I'll tell you what I want you to do over the next 8 to 12 hours", they'll say "fine". Here in this country there is more of a culture of saying "No, that is not what I was contracted to do" and I'd rather sit and do what I know well and not take any risks and follow my usual routines". That means that over the years, because of union demands, the ordinary workforce has become accustomed to a quality of life which is well beyond the quality of life experienced in the rest of the world, so they became price uncompetitive. Politically that is a problem for us.'

A strong underlying worry about declining quality emerged throughout the interviews, where concerns were expressed very strongly and clearly by workers, although the management was more cautious. Quality checks (at the time of our interviews, only second proofs were being checked in the UK) were disclosing major problems. It seemed likely that the handover process would take longer than originally anticipated. Despite training, quality was worse than expected although one manager insisted that the company recognised the learning curve their Indian colleagues were on and believed that with continuous training and feedback performance would improve. There was however, a considerable sense of pessimism and 'what if it won't work?'. One manager said:

'We've told our suppliers that their performance has to improve and that is about all we can do for the time being.'

Moreover, he added, if the relocation to India fails, there will always be other countries to consider. This manager also insisted that the company had not abandoned its UK workforce but was building a new skills base there, although he admitted that it would be unpopular because the work was so standardised:

'they won't like it so much as it is more boring than the work they used to do'.

Adding,

'There is a lot of resentment among our workforce but they will get used to their new jobs'

\section{The UK Trade Union perspective}

A trade union was actively involved in the negotiation around the voluntary redundancies, having been approached by the case company's senior management at a 'fairly early stage', (compared with other UK organisations planning to downsize; UK law requires companies to notify the union in advance if more than 20 redundancies are planned).

The initial intention was to make 60 people redundant over a three year period. A voluntary redundancy package was on offer with the option of taking up redeployment. The union representative recalls a series of 'heated, serious arguments' at the first meetings between the workforce and management. As already noted, the situation 
escalated when it was announced that six Indian workers would be trained within the reading department, mainly by workers who would eventually lose their jobs to India. Workers approached the trade union declaring that they would strike over this decision. The union strongly objected, making it clear that they would not support any strike action effectively saying:' You've got to do this, it's an order'. Both the management and the trade union representative admitted that this was a significant moment causing 'a lot of resentment and bitterness'. After this escalation workers seemed to come to terms with the finality of the management's intentions and an atmosphere of resignation spread, summed up in the words ' We might as well get the best deal of out this' .

Asked for a response to the company's argument that the UK workforce lacked flexibility, the union representative, somewhat surprisingly, appeared to agree with it. 'If the workers I am representing hear me say that, they'll wonder why I'm not part of the management. But I do think that as a workforce these people "unlearned" to appreciate their jobs and are less willing to try new things.'

Adding to that, he admitted that their union power did not really impact on the company's decision to relocate and pointed out that a more effective way to avoid redundancies would have been to find ways, possibly through worker consultation with management and trade unions, to make this workforce more flexible. But in his view there was no longer any scope for trying anything like that.

From the union perspective, it was felt that the situation was very clear: the number

of redundancies was not drastic and the management had quickly accepted a 'generous

redundancy package' with 18 months' salary being paid out. For the few workers who opted to be retrained, it was negotiated that none would be employed on worse terms than those specified in their existing contracts - especially important for the readers and copy-editors who would be moving to less-skilled work. His conclusion was stark:

'This is the reality trade unions have to live with. 'Let's face it, we have to accept that publishing is now a sunset labour market in Britain'.

\section{The Indian Story}

Five semi-structured interviews, each approximately one hour in length, were carried out with managers and employees in the Indian 'destination' company. There was no trade union presence in the company.

Most of its employees are women aged between 24 and 28. Roughly half are married and some also have children. Most are graduates and some have a technical background, with qualifications in IT or printing technology; others have a degree in the humanities. All members of the copy-editing team have postgraduate qualifications, either an M Phil or a PhD.

Although low by European standards ${ }^{7}$, remuneration in the offshoring sector

$7 \quad$ According to one of our respondents the cost per 1,000 characters for processing an electronic file 
(known in India as the Business Process Outsourcing, or BPO, sector) is well above the levels paid in other local industries so it is not difficult to attract educated Englishspeaking graduates. The company claims to follow a policy of hiring employees from lower and middle income families in the belief that in doing so it is contributing to wealth building in Indian society.

However these relatively high pay levels place workers above the salary ceiling offering working hours protection and overtime pay for weekend and evening work. This means that little extra compensation is provided for late and weekend work. The need to work anti-social hours is especially off-putting for women. As the company's HR manager put it,

'We would like to hire a few more men. One of the problems that we face is that many of the women don't want to work over the weekends. They may be ready to work on Saturdays, but certainly not on Sundays, especially the married women, with family and children. Many of the employees depend on public transport for commuting and are particularly reluctant to stay late in the evening.'

The 'flexibility' of the Indian workforce which figured so prominently in the UK interviews is experienced on the ground as highly problematic. The average time schedule for a particular job is three or four days, but may be as little as 24 hours and is never longer than a week. Whilst the typesetting work done by the company usually allows some leeway, nearly all the editorial work coming from the case study company is 'rush jobs'. Nevertheless, because it is more profitable than typesetting, the company continues to seek out this work. In the director's view, the last-minute nature of the work is inevitable. 'This is the nature of the publishing industry. All the time lost in earlier stages like receiving manuscripts and so on has to be made up for during this period'. However a middle manager said that he thought the outsourcing arrangement made it easier for the UK managers to get away with incompetent management practices, leaving things until the last minute or failing to give clear instructions, in the knowledge that these inadequacies would be invisible to their British colleagues and that the Indian outsourcers would have to 'pick up the pieces.' 'Flexibility' in Britain translates into management challenges as well as stress for workers in India.

'For the rush jobs, work allocation among the employees so that there is a more or less equitable workload is the challenge... Most of the time, the rush jobs are entrusted to a single group who have to co-ordinate the work amongst themselves ... there is a higher degree of monitoring for these jobs.'

Because so many steps are involved, the knock-on effect of compressing the schedule for any particular journal issue is considerable. During the short period of time allowed for any given job, a large number of separate tasks have to be carried out. Once the goahead is given, the papers and manuscripts are downloaded from the client site through FTP (file transfer protocol); these manuscripts are then distributed to a four-member team of readers for pre-production preparation (which normally takes about two days). The readers check the documents for missing pages, artwork graphics and other details

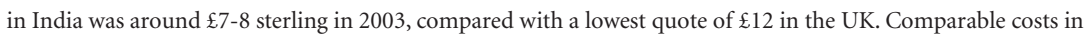
the USA were \$25-32 US as compared with around \$18 per 1,000 characters in India. Copy- editing is the process that generates the highest added value in the business. 
as well as checking the readability of the document for typing and coding. Dealing with any missing items or inconsistencies requires liaison with the client.

The manuscript then goes into production. In the first step (coding) the document is formatted to produce galleys which are checked against the original manuscript in a proof-reading step. The mistakes found during the proof-reading are corrected in the next step by a team of four people. After these corrections, the manuscript may be sent back to the client or processed further. In the next step, the manuscripts are put into the appropriate house style for the specific journal.

Next comes the pagination of the whole journal issue, following which the table of contents is produced and a final check of the style (including hyphenation) is carried out. A further quality check is then carried out by a group of four senior people before the issue is uploaded to the client site by FTP. If any of the authors want additional corrections to be made, these too are carried out by the Indian company before the journal is finally printed. Each step is monitored using workflow software.

This is exacting, painstaking work, requiring a range of different specialist skills and knowledge, the ability to make judgements about the use of language and an eye for detail. Having to do it under pressure makes it stressful, a stress which may be increased by the knowledge that the speed at which the work is carried out is being closely monitored. Burnout and high staff turnover are not unexpected in such circumstances.

Despite their general statements of confidence in the future growth of their company, it is clear that some clouds hang over the future of its relationship with the case study company in the UK. With the trend towards more online publishing, the UK company has reduced its dependence on the proprietary software in which the Indian company has invested so much staff training effort and is moving towards the use of standard off-the-shelf publishing software packages. This has eroded their competitive advantage. Although it does make it easier for them to approach other clients in the publishing industry, it also poses a threat: any company can now move its business easily from one vendor to another, since the underlying technologies are the same. The only recourse left to the company in this scenario is to continuously strive to reduce costs, improve quality and efficiency and introduce better work processes. This puts constant pressure on the workforce to meet ever more exacting standards.

Although the UK company had not informed them that they had already shifted much of their business to a rival company in another part of India (or, indeed, that they were also investigating outsourcing some work to China), this company had noticed a reduction in the flow of work. As one manager put it:

'Though in the normal business itself, there are some variations in the number of pages received for working, over the last few months the quantum of work from this source has also been decreasing ... It has made the employees nervous and they are feeling insecure and worried about their future.'

The response has been to search actively for new business. The company still expects to expand its operations in the near future. They are targeting new customers in Europe and the USA and have also approached Australian companies for outsourcing contracts.

Even it they are successful in this aim, however, given the competitiveness of the market, it is not at all clear whether this will necessarily result in sustainable employment. 


\section{Conclusions}

Most of the literature on the employment effects of offshore outsourcing (e.g. Bardhan \& Kroll, 2003, Norwood, et al 2006, Sako, 2005, Pain \& van Welsum, 2004, van Welsum \& Reif, 2006, UNIFI, 2002) has focused on the numbers of jobs affected, reflecting public panics about the mass migration of employment from the developed economies of the North to the global South.

This case study, along with many others carried out by the EMERGENCE team (Flecker \& Kirschenhofer, 2002, Huws and Flecker, 2004) suggests that the qualitative impacts on work, and on workers' security may in fact be much greater than the quantitative effects. To take the example of the English-language academic publishing industry, there is every likelihood that it will continue its exponential growth. In the words of one market survey of Scientific, Technical and Medical (STM) publishing: 'The niche nature of the market and the rapid growth in the budgets of academic libraries have combined to make scientific publishing the fastest growing subsector of the media industry over the past 15 years. Moreover, the STM market is quite insensitive to the ups and downs of the economy and therefore a stable and reliable field for long-term investments.' (versita.com, undated)

This suggests a net worldwide growth in jobs, a growth which may well more than compensate numerically in any given European country for jobs relocated to other parts of the world (Huws, 2004). As the trade union officer interviewed in the UK observed, the actual number of jobs lost in this relocation was not huge and it seems likely that most of the workers displaced found themselves some sort of alternative employment, albeit more precarious, as freelance proof-readers or editors. Nevertheless, major damage was done: to their pride in their work, their trust in their employer, their confidence in their trade union, their self-respect, their sense of their worth on the labour market, the security with which they could look forward to the future and (in their view) also to the quality of the brand which they had devoted decades of their working lives to building up.

Their experiences could be multiplied across an industry which in the 20th century was one of a very few that offered satisfying work to well-educated women and men who wanted some connection with the world of ideas whilst still earning a modest living, people who were prepared to sacrifice high wages for the sake of doing a worthwhile job with intrinsic rewards. Their shock and disappointment stands in for a broader disenchantment; their new precariousness symbolises that of many. Several of our respondents clearly saw themselves as representing the tip of an iceberg. As one put it,

"If reading can be done in India, why not database management and spreadsheet handling?'

It could be argued that they represented a labour elite, late survivers of a privileged layer that waxed fat on the remains of the British Empire. If the highly educated young women in India who are now doing their former work enjoyed the prestige and security that publishing work seemed to offer at its best in the UK inthe 20th century, then this could indeed be seen as a kind of poetic justice. The reality revealed by this case study, however, suggests that the new precariousness has not only been exported along with the jobs but magnified in the process. The introduction of generic software and standardised processes, in combination with the outsourcing relationship, has reduced the 
mutual commitment of the parties, forcing suppliers to compete against many others in a globalised market for increasingly standardised skills, where both their performance and their prices can be continuously compared with those of their competitors. The pressures are passed down the line with the 'crunch' falling on the workers who are unlucky enough to be squeezed closest to the deadline, and furthest from the centres of power. These stresses are evidenced in dramatically higher rates of staff turnover in the new Indian workforce (with a typical tenure of less than three years) compared with the older UK workforce (with a typical tenure of over 20 years).

Although a literature on globalisation, company strategies and offshoring is now emerging, few studies have taken a qualitative approach and even fewer have placed the study of outsourcing within a context of other factors taking place within organisations enabling workers's perceptions of precariousness to be studied (Benson \& Littler 2002). There is, however, an extensive body of research linking the concept of job precariousness to the effects of redundancies and unemployment on workers (Frechet, Langlois \& Bernier 1992). Research looking at job precariousness also illustrates the psychosocial impacts on workers in situations of growing employment insecurities (Malenfant, LaRue, Mercier and Vezina 2002). Fear of losing one's job, a lack of coping strategies, financial instability and adverse health effects may all be outcomes of insecure work situations. A review of studies (Quinlan, Mayhew \& Bohle 2001), linking precarious working conditions to occupational health and safety found that precarious employment was associated with a deterioration in occupational health and safety in terms of injury rates, disease risk and hazard exposures. The same review identified a negative association between occupational health and safety and companies that are involved in outsourcing and organisational downsizing. Such heightened job insecurities interact with the already greater sense of precariousness experienced by most part-time, freelance and other contractual work contributing a further source of stress. Whether workers remain in employment or go freelance, it seems that there is no escape from these pressures.

Requirements for flexibility and adaptability can be factors closely linked to the precarisation of work. From the employer's perspective, flexibility offers a way to adapt to an increasingly unstable economic environment. For the workers, on the other hand, the requirement to be more flexible may weaken contractual and other employment conditions. The search for flexibility emerged as a prime motive to outsource to India in this case study company.

Added to these interlinked effects is another: the impact of changes in skill requirements. For the minority of UK workers in this case study who chose not to take voluntary redundancy, the only other choice was to accept much more standardised, lower status work. Adjusting to these new skills meant a development, which, according to these interviewees, felt very alien to them compared with the work they were used to. A subtle process of deskilling can be observed as new job requirements sidestep the existing skills base in favour of a new one. In this process, the old skills are devalued and workers feel that they are becoming more interchangeable. Even if they do not fall into objective definitions of precariousness (e.g. because they still have full-time permanent jobs) the subjective experience is nevertheless one of replaceability. The knowledge that 
the job might go offshore hangs like a sword of Damocles over their heads even if the threat is never realised. It may therefore be more useful to see the impact of offshore outsourcing not so much as the displacement of jobs but as rendering them more precarious. In other words offshoring's primary impact on labour is to discipline it rather than eliminate it altogether.

This case study also raises large questions about the role of trade unions in representing their members whose jobs are affected by offshore outsourcing. The interview accounts painted an ambiguous picture: on the one hand, the trade union had provided professional support in negotiating redundancy packages that were reasonably generous (by British standards); on the other it had refused to support the workers in their dispute with management. Although it was evident that there were broader concerns within the union about the increasing numbers of local job losses to India, an effective strategy on how to counter them had not yet been visualised. The editorial workers interviewed made it clear that they wanted more support than they had been offered to help them come to terms with their new condition, support that they felt should have been offered by both management and trade union.

We can conclude that trade unions need to develop strategies that will enable them to transcend national borders as easily as their employers. If not, as the sun sets on their traditional fields of negotiation, there is a danger that they could become increasingly marginal.

\section{(C) Simone Dahlmann and Ursula Huws, 2006}

\section{REFERENCES}

Bardhan, A.D. and C. Kroll (2003) The New Wave of Outsourcing, Berkeley Ca: Fisher Center for Real Estate and Urban Economics, University of California

Benson, J. \& Littler, C (2002) Outsourcing and workforce reductions: an empirical study of Australian organizations, Asia Pacific Business Review, 8,3, 16-30

The Economist, 'Outsourcing to India: Backroom deals', 2003, 22-28t February:86-89.

Flecker, J. \& Kirschenhofer, S. (2002) Jobs on the Move: European Case studies in relocating eWork,IES Report 386, Brighton: Institute for Employment Studies

Frechet, G., Langlois, S. and Bernier, M. (1992), Transition in the labour market - a longitudinal perspective, Industrial Relations Journal, 47:79-99

Huws, U. \& O'Regan, S. (2001) eWork in Europe: The EMERGENCE 18-Country Employer Survey,IES Report 380, Brighton: Institute for Employment Studies

Huws, U. (2003) When Work Takes Flight: Research Results from the EMERGENCE Project, IES Report 397, Brighton: Institute for Employment Studies

Huws, U.,S. Dahlmann and J. Flecker (2004) Status Report on Outsourcing of ICT-enabled Services in the EU, Dublin: European Monitoring Centre on Change of the European Foundation for the Improvement of Living and Working Conditions

Huws, U. (1988), 'Remote Possibilities: Some difficulties in the analysis and quantification of telework in the UK. In: Korte, W.B., Robinson, S. and Steinle, W.J. (eds), Telework: Present situation and future development of a new form of work organization, Amsterdam: Elsevier Science Malenfant, R., LaRue, A., Mercier, L. \& Vezina, M (2002), Job precariousness, work relations and social integration, Nouvelles pratiques socials, 15:11-130.

McCarthy, J.C, Belanger, N. \& Orlov, L.M. (2003), Unlocking The Savings In Offshore, Cambridge Ma: Forrester Research Report

Norwood, J., C. Carson, M. Deese, N .J. Johnson, F. S. Reeder, J.E.Rolph \& S. Schwab (2006)Offshoring: an Elusive Phenomenon, Washington D.C.: National Academy of Public Administration 
Quinlan, M, Mayhe, C \& Bohle, P (2001) 'The global expansion of precarious employment, work disorganization, and consequences for occupational health: a review of recent research', International journal of health services, 31, 2:335-414

Sako, M (2005) Outsourcing and Offshoring: Key Trends and Issues, Oxford: Said Business School Stanworth, C. \& Stanworth, J. 'The Self-Employed without employees - Autonomous or Atypical?' Industrial Relations Journal, 1995, 26:3:221-229

Stanworth, C. \& Stanworth, J. Managing an externalised workforce: freelance labour-use in the UK book publishing industry. Industrial Relations Journal, 1997, 28,1:43 - 54.

UNIFI (2002) Globalisation and the trade union movement - What is the true cost of outsourcing? London: UNIFI

Pain, N. and D. van Welsum (2004) International Production, Relocation and Exports of Services, Paris: OECD

Parker, A (2004) Two-speed Europe: Why 1 Million Jobs will Move Offshore, Cambridbge Ma: Forrester Research

Van Welsum, D. and X Reif (2006) The Share of Employment Potentially Affected by Offshoring: an Empirical Investigation, Paris: OECD

Vendramin, P, Valenduc, G., Richardson, R., Carre, D, et al (2000). Flexible work practices and communications technology, Brussels: European Commission

Versita.com (undated) STM Publishing Industry and Market. Retrieved on November 5, 2006 from http://versita.com/UserFiles/File/STM Publishing Industry and Market.pdf

\section{ACKNOWLEDGEMENTS}

We would like to thank Rajendra Bandi and Vasanthi Srinivasan at the Indian Institute of Management in Bangalore, India for carrying out the research in India for this case study. The Asian EMERGENCE project, within whose scope this research was carried out, was funded by the European Commission's Europeaid Programme (Asia IT@C Programme). Ursula Huws directed the project in her capacity as an Associate Fellow of the Institute for Employment Studies, in Brighton, UK. Further information about the EMERGENCE project can be found on http://www.emergence.nu 